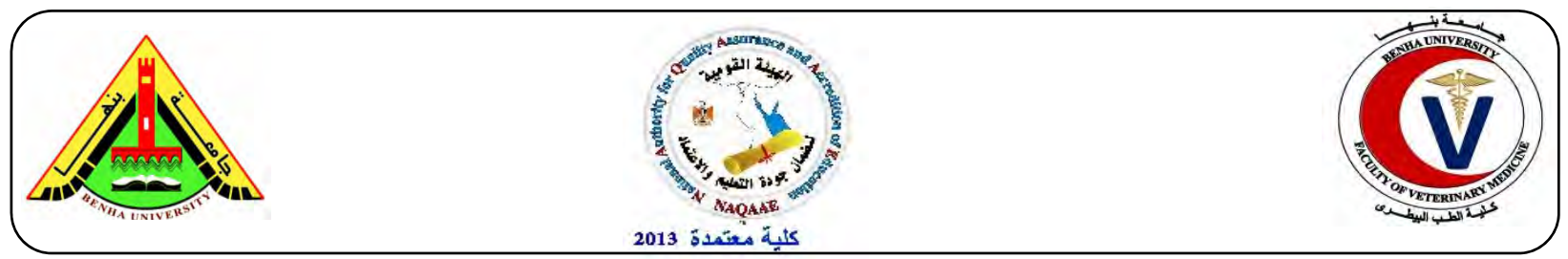

\title{
Effect of storage on the activity of the bacteriocin extracted from Lactobacillus acidophilus
}

\author{
Hamdi M. Abdelsamei ${ }^{1}$, Ekbal M. A.Ibrahim ${ }^{1}$, Sobhy A. EI Sohaimy ${ }^{2}$, Marwa A. Saad ${ }^{1}$ \\ ${ }^{1}$ Department of Food Control, Fac. of Vet. Med., Benha Univ., Egypt. ${ }^{2}$ Food Technology Department \\ arid land research institute city of scientific Research and technology application
}

\section{A B S T R A C T}

Bacteriocins are extra-cellular released peptides or protein with a bactericidal or bacteriostatic mode of action against many Gram positive and Gram negative bacteria. Bacteriocins produced by lactic acid bacteria (LAB) have received particular attention in recent years due to their potential application in the food industry as natural preservatives. In this study, bacteriocin was extracted from Lactobacillus acidophilus to determine its inhibitory effect against Bacillus subtilis, Staph.aureus (Gram-positive bacteria) and E.coli (Gram-negative bacterium). The largest inhibition zone was obtained against Bacillus subtilis followed by Staph.aureus while the smallest inhibition zone was obtained against E.coli. The results revealed that the activity of bactericin extract was gradually decreased during storage at $37^{\circ} \mathrm{C}$ until 60 days and it was completely lost up to 90 days of storage. It was stable at $4^{0} \mathrm{C}$ until 30 days then its activity was gradually decreased till 90 days of storage. While, the storage of extracted bacteriocin at $-20^{\circ} \mathrm{C}$ persisted its activity for 90 days. The current study concluded that freezing temperature was the most appropriate technique for preservation of bacteriocin.

Keywords: Lactic acid bacteria, Lactobacillus acidophilus, Bacteriocin and Storage temperature.

(http:// www.bvmj.bu.edu.eg)

(BVMJ-28(1): 216-222, 2015)

\section{INTRODUCTION}

$\mathrm{n}$ spite of modern advances in technology, the preservation of foods is still a debated issue, not only in developed countries but also in the industrialized world. The empirical use of microorganisms for the preservation of food (biopreservation) has been a common practice in the history of mankind. Lactic acid bacteria (LAB) is one of bacteria commonly used in food preservation due to production of antimicrobial substances such as bacteriocins, organic acids, hydrogen peroxide, reuterin, reutericyclin and antifungal peptides (Rajaram et al., 2010). Bacteriocins are antimicrobial peptides synthesized by ribosomes of bacteria which have the property of inhibiting food spoilage and food-borne pathogenic bacterial species including Bacillus, Clostridium, Staphylococcus and
Listeria (Cotter et al., 2005). Therefore, bacteriocins of $\mathrm{LAB}$ are of particular interest because of their existing and potential applications as natural preservatives in food. The first and more famous bacteriocin to both the European food additive list and the United States FDA list is nisin, which was intended for use in the production of pasteurized processed cheese (Forouhandeh et al., 2010). Bacteriocins have been grouped into 4 main classes based on their chemical and genetic properties (Kaiserlian et al., 2005 and Dimitrijevic et al., 2009). Class I the lantibiotics; class II, the non-lantibiotic peptides, which are divided into the subgroups IIa: peptides active against Listeria, the characteristic representants are pediocin PA-1 and sakacin P, IIb: bacteriocins whose activity depends on the 
complementary action of two peptides, and IIc sec-dependent secreted bacteriocins; class III, large, heat-labile protein bacteriocins. The class IV bacteriocins are a group of complex protein, associated with other lipids or carbohydrate moieties. They are relatively hydrophobic and heat stable (Z'Graggen et al., 2005). Most of the bacteriocins from LAB have been isolated from species of the genus Lactobacillus, probably because of the diversity of its species and habitats. Lactobacillus acidophilus is one of LAB group widely used in fermented milk products such as acidophilus yoghurt and sweet acidophilus milk. It has been found that, majority of $L b$. acidophilus strains produce bacteriocins. Lactacin B was the first antimicrobial peptide from $L$. acidophilus that was undoubtedly identified as a bacteriocin (Oh et al., 2000). Besides their application in food industry and their relevance in the improvement of food quality and safety, the increased interest in bacteriocinogenic $\mathrm{LAB}$ strains have been ascribed to their potential to modulate the immune system (Kaiserlian et al., 2005). Lactobacillus acidophilus DSM 20079 produces a heat-stable peptide bacteriocin named acidocin D20079, active for 2 months at $4^{0} \mathrm{C}$ and in frozen state over 6 months intended it suitable for preservation in food industry (Deraz et al., 2005). In sight to these facts, the present work aimed to extract the bacteriocin from Lactobacillus acidophilus and study its antibacterial activity against Bacillus subtilis, Staph.aureus (Gram-positive bacteria) and E.coli (Gram-negative bacterium) and detect its stability during storage at different temperatures for 90 days.

\section{MATERIAL AND METHODS}

\subsection{Activation of Lactobacillus acidophilus:}

Lyophilized strain of L. acidophilus DSMZ 20079 was obtained from MIRCEN (Microbiological Resource Center), Faculty of Agriculture, Ain Shams University,
Cairo, Egypt. Lactobacillus acidophilus strain was activated on MRS broth (De Man, Rogosa and Sharp which obtained from Biolife, Italy) at $37^{\circ} \mathrm{C}$ for $24 \mathrm{hrs}$. Serial dilutions were prepared till obtaining the concentration of $10^{7}-10^{9} \mathrm{CFU} / \mathrm{mL}$ in order to meet the required recommended level for active probiotic (IDF, 1988).

\subsection{Extraction of bacteriocin:}

Ten $\mathrm{mL}$ of activated L. acidophilus culture was inoculated into one liter of MRS broth under aseptic conditions (Chumchalova et al., 2004). The activated culture was adjusted to $\mathrm{pH} 2.0$ by adding HCL $1 \mathrm{~N}$ then culture was heated in a water bath at $100{ }^{\circ} \mathrm{C}$ for $5 \mathrm{~min}$. The cells were harvested by centrifugation at $10,000 \mathrm{rpm}$ for $20 \mathrm{~min}$ at $4^{0} \mathrm{C}$. The cell-free supernatant containing bacteriocin extract was adjusted to $\mathrm{pH} 6.0$ using $\mathrm{NaOH} 1 \mathrm{M}$ to exclude the effect of organic acids. The bacteriocin extract was sterilized by using Seitz filter to eliminate the rest of viable cells (Simova et al., 2009).

\subsection{Determination of antibacterial activity:}

Bacteriocin activity was assayed by agar well diffusion method according to Tahara and Kanatani (1996), with some modifications as described by Todorov and Dicks (2004) as follows: Separately, $1 \mathrm{ml}$ from approximately $1 \mathrm{X} 10^{6} \mathrm{CFU} / \mathrm{ml}$ of each indicator pathogenic strains including Bacillus subtilis, Staph.aureus (Grampositive bacteria) and E.coli (Gramnegative bacterium) was inoculated into sterilized Petri dishes and poured on Muller Hinton agar then leaving the plates for solidification. $100 \mu \mathrm{l}$ of two fold serial dilutions of sterilized bacteriocin were inoculated into wells which made on the solidified agar with sterile cork borer (10 $\mathrm{mm}$ in diameter). Pre diffusion at $4^{\circ} \mathrm{C}$ for 2 4 hours was allowed prior to incubation at $37^{\circ} \mathrm{C} / 24 \mathrm{hr}$ and then examined for clear circular inhibition zone around the wells. The titer of inhibition was defined as the reciprocal of the highest dilution showing definite inhibition zone and was expressed 
as activity units (AU) per $\mathrm{ml}$. The activity unit $(\mathrm{AU} / \mathrm{ml})$ was calculated according to the following formula: $\mathrm{AU}=(1000 / \mathrm{V}) 2^{\mathrm{y}}$ Where, AU is arbitrary unit of bacteriocin activity. $\mathrm{y}$ is the number of the last dilution showing inhibition. $\mathrm{V}$ is the volume of the supernatant $(\mu 1)$ which inoculated in each well. Bacteriocin activity was recorded as positive if the width of the clear inhibition zone around the colonies of the producer was $2 \mathrm{~mm}$ or larger (Chumchalova, et al., 1995 and Anastasiadou, et al., 2008). The experiment was repeated 3 times.

\subsection{Effect of storage temperature on bacteriocin activity:}

The crude bacteriocin extracted from $L b$. acidophilus DSM 20079 was examined for stability during different storage temperature for different time. About $5 \mathrm{ml}$ of Crude bacteriocin was stored at different temperatures $\left(37^{\circ} \mathrm{C}, 4^{0} \mathrm{C},-20^{\circ} \mathrm{C}\right)$. Then bacteriocin activity was assayed by agar well diffusion method against lactobacillus species (Ogunbanwo et al., 2003 and Rajaram et al., 2010).

\subsection{Statistical analysis:}

Statistical comparisons were made by using one-way analysis of variance (ANOVA). The results were considered significantly different with $\mathrm{P}<0.05$ as described by (Clarke and Kempson, 1997).

\section{RESULTS}

Bacteriocins are generally low molecular weight proteins have bacteriocidal effect on Gram-positive bacteria and bacteriostatic action on Gram-negative bacteria (Klaenhammer, 1993 and Nes et al., 1996).

\subsection{The antibacterial activity of Lactobacillus acidophilus bacteriocin:}

Bacteriocin was firstly extracted from $L$. acidophilus then determined its inhibitory effect against Bacillus subtilis and Staph.aureus (Gram-positive bacteria) and E.coli (Gram-negative bacterium). The largest inhibition zone was obtained by bacteriocin extract against Bacillus subtilis then Staph.aureus while the smallest inhibition zone was against E.coli.

\subsection{Effect of storage temperature on bacteriocin activity:}

The results revealed that the activity of extracted bactericin was gradually decreased during storage at $37^{\circ} \mathrm{C}$ until 60 days and it was completely lost up to 60 days of storage with significantly difference $(P<0.05)$ as in Table (1). Table (1) showed that the extracted bacteriocin was stable at $4^{0} \mathrm{C}$ until 30 days then activity was gradually decreased throughout 60 to 90 days of storage. There were significantly difference $(P<0.05)$. While, the activity of the extracted bacteriocin was persisted for 90 days at $-20^{\circ} \mathrm{C}$ and there were no significance between data about these results as the activity during the storage period as showed in Fig. (2).

\section{DISCUSSION}

Bacteriocins have caught the attention of food scientists to be used as natural food biopreservtives due to their antimicrobial activity against food spoilage and pathogenic bacteria. The Preservative action of lactic acid bacteria is due to production of lactic acid, acetic acid, hydrogen peroxide as well as bacteriocin which resulting from its metabolic activity (Cleveland et al., 2002; Gautam and Sharma, 2009). For application of crude bacteriocin only as food preservatives, the action of hydrogen peroxide was excluded by heat treatment at $80^{\circ} \mathrm{C}$ for $10 \mathrm{~min}$. and organic acids were excluded by neutralization at $\mathrm{pH}$ 7. The effect of bacteriocins extracted from $L$. acidophilus on the growth of some Gram-positive bacteria (Bacillus subtilis and Staph. aureus) and Gram-negative bacteria (E.coli) had been investigated. The obtained results from Figure (1) showed that the antibacterial activities of $L b$. acidophilus bacteriocin which was recorded by the diameter of inhibition zone $(\mathrm{mm})$ with mean values of $14.5,12.5$ and $10.0 \mathrm{~mm}$ against $B$. 
Figure (1) antibacterial activity of bacteriocin produced by Lactobacillus acidophilus bacteriocin

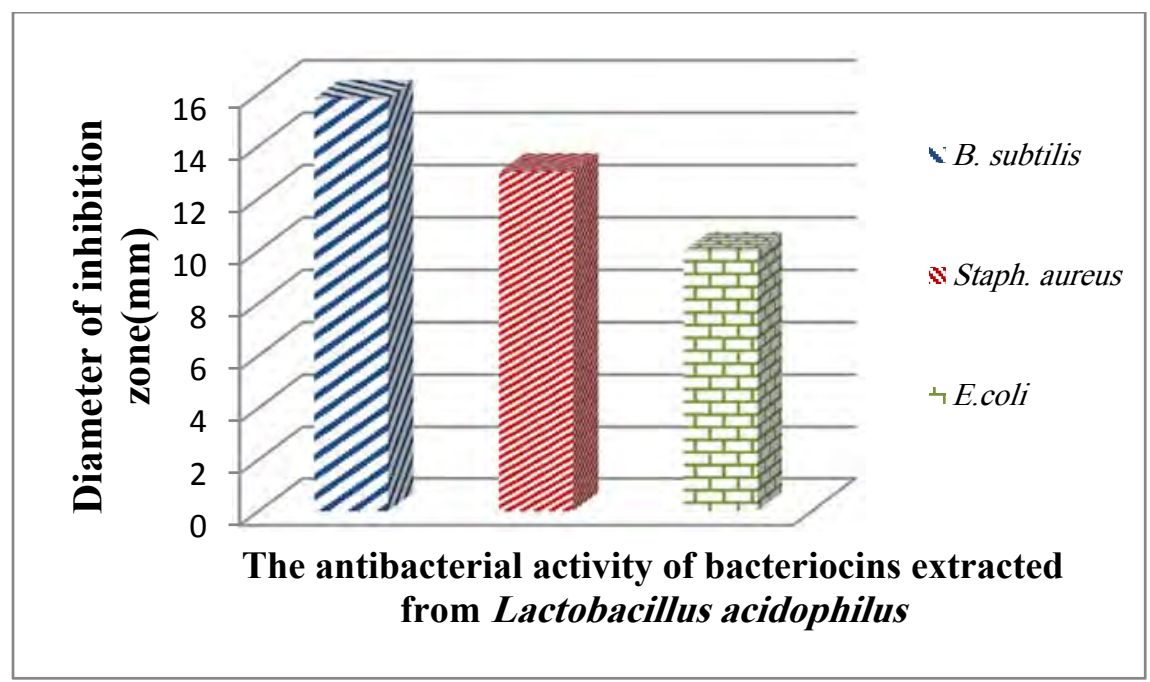

Table (1): Effect of storage at temperature $\left(\sim 37^{0} \mathrm{C}\right)$ on the stability of Lactobacillus acidophilus bacteriocin

\begin{tabular}{cccc}
\hline & \multicolumn{3}{c}{ Diameter of inhibition zone $(\mathrm{mm})$} \\
\hline Storage period (days) & Bacillus subtilis & Staph. aureus & E.coli \\
\hline Fresh & $14.5 \pm 0.57^{\mathrm{a}}$ & $12.5 \pm 0.39^{\mathrm{a}}$ & $10 \pm 0.34^{\mathrm{b}}$ \\
15 & $10 \pm 0.34^{\mathrm{a}}$ & $8.5 \pm 0.25^{\mathrm{b}}$ & $6.5 \pm 0.08^{\mathrm{c}}$ \\
30 & $5.5 \pm 0.03^{\mathrm{a}}$ & $5 \pm 0.02^{\mathrm{a}}$ & $3.5 \pm 0.04^{\mathrm{b}}$ \\
60 & $3 \pm 0.05^{\mathrm{a}}$ & $2.5 \pm 0.04^{\mathrm{b}}$ & $1.00 \pm 0.05^{\mathrm{c}}$ \\
90 & $\mathrm{ND}$ & $\mathrm{ND}$ & ND \\
\hline
\end{tabular}

$\mathrm{a}, \mathrm{b}$, c mean values in the same raw having different superscripts letters are significantly different $(\mathrm{P}<0.05)$ ND not detected

Results are mean of three determination $(n=3)$

Figure (2): Effect of storage at refrigerating temperature $\left(\sim 4^{0} \mathrm{C}\right)$ on the stability of Lactobacillus acidophilus bacteriocin

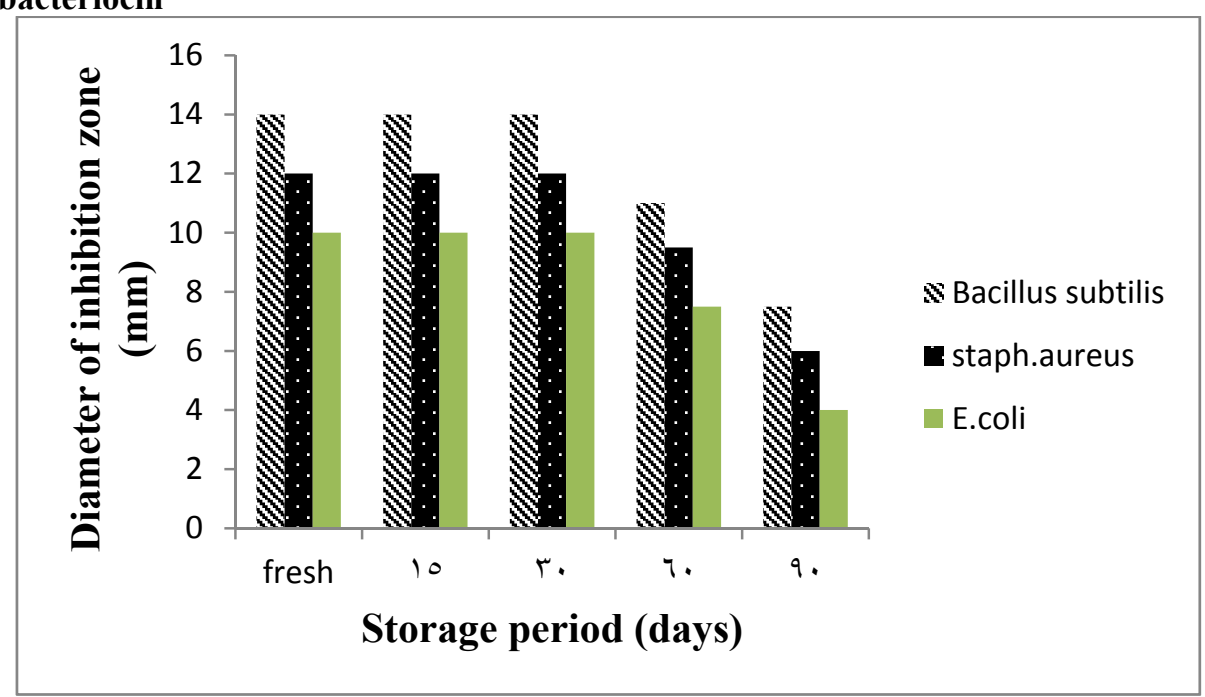

Results are mean of three determination $(n=3)$ 
Table (2): Effect of storage at freezing temperature $\left(\sim-20^{0} \mathrm{C}\right)$ on the stability of Lactobacillus acidophilus bacteriocin

\begin{tabular}{cccc}
\hline & \multicolumn{3}{c}{ Diameter of inhibition zone (mm) } \\
\hline Storage period (days) & Bacillus subtilis & Staph. aureus & E.coli \\
fresh & $14.5 \pm 0.57^{\mathrm{a}}$ & $12.5 \pm 0.39^{\mathrm{b}}$ & $10 \pm 0.24^{\mathrm{c}}$ \\
15 & $14.5 \pm 0.57^{\mathrm{a}}$ & $12.5 \pm 0.39^{\mathrm{b}}$ & $10 \pm 0.24^{\mathrm{c}}$ \\
30 & $14.5 \pm 0.57^{\mathrm{a}}$ & $12.5 \pm 0.39^{\mathrm{b}}$ & $10 \pm 0.24^{\mathrm{c}}$ \\
60 & $14.5 \pm 0.57^{\mathrm{a}}$ & $12.5 \pm 0.39^{\mathrm{b}}$ & $10 \pm 0.24^{\mathrm{c}}$ \\
90 & $14.5 \pm 0.57^{\mathrm{a}}$ & $12.5 \pm 0.39^{\mathrm{b}}$ & $10 \pm 0.24^{\mathrm{c}}$ \\
120 & $\mathrm{ND}$ & $\mathrm{ND}$ & $\mathrm{ND}$ \\
\hline
\end{tabular}

a, b, c mean values in the same raw having different superscripts letters are significantly different $(P<0.05)$ ND not detected. Results are mean of three determination $(n=3)$

subtilis, Staph. aureus and E. coli, respectively. These results agreed to some extent with those reported by Carrasco et al. (2002) and Simova et al. (2009). The sensitivity of Gram-positive and Gramnegative bacteria towards different bacteriocins has been demonstrated on the basis of cell wall composition. The relatively resistance of Gram-negative bacteria is attributed to the particular nature of their cellular envelope which composed of lipopolysacchride, protein and phospholipids. In addition the presence of pores which allow the free diffusion of molecules with low molecular weight $(<600$ Da) while the smallest bacteriocins are approximately $3 \mathrm{KDa}$ (Abee et al., 1995 and Ray et al., 2001). In the present study, the effect of storage time - temperature on the antibacterial activity of extracted bacteriocin was carried out. Table (1) showed that the effect of storage at $37^{\circ} \mathrm{C}$ on the stability of bacteriocin extracted from $L$. acidophilus DSM 20079. The effect was determined against Bacillus. subtilis, Staph. aureus and E. coli by agar well diffusion method for 3 months at intervals of 0,15 , 30, 60 and 90 days. The inhibition zone of the extracted bacteriocin was $14.5,12.5$ and $10 \mathrm{~mm}$ for Bacillus. subtilis, Staph. aureus and E. coli, respectively. On contrary, the bacteriocin activity was gradually decreased by progressive of storage and reached to $5.5,5$ and $3.5 \mathrm{~mm}$ after 30 days of storage. After 90 days of storage at $37^{\circ} \mathrm{C}$ the activity of the extracted bacteriocin was completely lost. Banerjee et al. (2013) reported similar results with bacteriocin of
L. brevis FPTLB3 where its stability decreased on $20^{\text {th }}$ day of storage at $37^{\circ} \mathrm{C}$. Malini and Savitha (2012) also found that the activity of bacteriocin extracted from $L$. acidoplius NCIM5426 was decreased within 20 days of storage at $32^{\circ} \mathrm{C}$. Figure (2) showed that the stable antibacterial activity of extracted bacteriocin from L. acidophilus at $4^{\circ} \mathrm{C}$ when fresh, after 15 days $\& 30$ days of storage with the diameter of inhibition zone of 14, 12 and 10 against Bacillus. subtilis, Staph. aureus and E. coli, respectively. However, the diameter of inhibition zone was decreased to 11,9.5 and $6.5 \mathrm{~mm}$ after 60 days of storage and reached to 7.5, 6 and $4 \mathrm{~mm}$ of diameter after 90 days of storage for Bacillus. subtilis, Staph. aureus and E. coli., respectively. These results are in accordance with those reported by Malini and Savitha (2012) as they found that the bacteriocin activity produced by $L b$. paracasei subsp. tolerans isolated from locally available cheese was more stable at $4^{0} \mathrm{C}$ for 30 days. The effect of storage at freezing temperature $\left(-20^{\circ} \mathrm{C}\right)$ on the antibacterial activity of the extracted bacteriocin is presented in table (2). The activity of bacteriocin was prolonged up to 90 days of storage at $-20^{\circ} \mathrm{C}$. The diameter of inhibition zones of the bacteriocin was 14.5, 12.5 , and $10 \mathrm{~mm}$ for Bacillus. subtilis, Staph. aureus and E. coli., respectively when fresh and remained stable after 30, 60 \& 90 days. During further storage period (120 days) the activity was not detected. The results come in accordance with those reported by Corsetti, et al. (2004) who found that the bacteriocin activity produced 
by lactobacillus spp. was stable during freezing for at least 3 months of storage. While, Ogunbanwo et al., (2003) reported that the bacteriocins produced by $L b$. brevis OG1 and $L$. plantarum were remained fully stable after storage for 60 days at $-20^{\circ} \mathrm{C}$. Storage of the active substance produced by L. acidophilus DSM 20079 at $4^{0} \mathrm{C}$ for more than 2 months and in frozen state over 6 months did also not influence the activity (Deraz, 2005). These results indicated that freezing temperature at $-20^{\circ} \mathrm{C}$ is the most appropriate preservation technique for bacteriocin. Finally, the achieved results allow to conclude that $L$. acidophilus bacteriocin has a broad spectrum of antibacterial activity against the examined pathogenic bacteria (Bacillus subtitles, Staph. aureus and E.coli). The ability of extracted bacteriocin in inhibiting of a wide-range of bacteria may be of potential interest for food safety and preservation providing future scope for application of $L$. acidophilus DSM 20079 as food preservative.

\section{REFERENCES}

Abee, T., Krockel, L. and Hill, C. 1995. Bacteriocins: mode of action and potentials in food Preservation and control of food poisoning. International Journal of Food Microbiology 28(2): 169-185.

Anastasiadou, s., Papagianni, M., Filiousis, G., Ambrosiadis, I. and Koidis, P. 2008. Pediocin SA-1, an antimicrobial peptide from Pediococidcus acidilacti NRRL B5627: production conditions, purification and characterization. Bioresource Technology, 99(13): 5384-5390.

Banerjee, S.P., Dora, K.C. and Chowdhury, S. 2013. Detection, partial purification and characterization of bacteriocin produced by Lactobacillus brevis FPTLB3 isolated from fresh water fish. Journal of Food science and Technology, 50(1): 17-25.

Carrasco, M.S., Scarinci, H.E. and Simonetta, A.C. 2002. Antibacterial activity of lactic acid bacteria isolated from Argentinean dairy products. The Australian Journal of Dairy Technology 57: 15-19.

Chumchalova, J., Josephsen, J. and Plockova, M. 1995. Characterization of acidocin $\mathrm{CH} 5$ a saccharolytic sensitive bacteriocin of Lactobacillus acidophilus CH5. Advances in Food Sciences17: 145-150.

Chumchalova, J., Josephsen, J., Plockova, M. 2004. Characterization and purification of acidocin $\mathrm{CH} 5$, a bacteriocin produced by Lactobacillus acidophilus CH5. Journal of Applied Microbiology 96: 1082-1089.

Clarke, G. M., Kempson, R. E. 1997. Introduction to the design and analysis of experiments. Arnold, a Member of the Holder Headline Group. 1 st ed., London, UK.

Cleveland, J., Chiknids, M. and Montiville, T.J. 2002. Multi method assessment of commercial nisin preparations. Journal of Industrial Microbiology and Biotechnology 29: 228-232.

Corsetti, A., Settanni, L., VanSinderen, D. 2004. Characterizations of bacteriocin like inhibitory (BLIS) from sourdough lactic acid bacteria and evaluation of their in vitro and in situ activity. Journal of Applied Microbiology, 96: 521-534.

Cotter, P.D., Hill, C. and Ross, R.P. 2005. Bacteriocins: Developing innate immunity for food. Nature Reviews Microbiology, 3: 777-788.

Deraz, S., Karlsson, N.E., Hedstrom, M., Andersson, M.M., Mattiasson, B. 2005. Purification and characterization of acidocin D20079 a bacteriocin produced by Lactobacillus acidophilus DSM20079. Journal of Biotechnology, 117: 343-354.

Dimitrijevic, R., Stojanovic, M., Zivkovic, I., Petersen, A., Jankov, R.M., Dimitrijevic, L. and Gavrovic, M.J. 2009. The identification of a low molecular mass bacteriocin, rhamnosin A, produced by Lactobacillus 
rhamnosus strain 68. Applied Microbiology, 2108-2115.

Forouhandeh, H., Zununi, V.S., Hejazi, M.S., Nahaei, M.R and Akbari Dibavar, M. 2010. Isolation and phenotypic characterization of lactobacillus species from various dairy products. Current Research of Bacteriology, 3(2): 84-88.

Gautam, N. and Sharma, N. 2009.Bacteriocin: Safest approach to preserve food products. Indian J. of Microbiology, 49: 204-211.

IDF (International Dairy Federation), 1988. Fermented milks: Science and technology. Bulletin of the IDF: In A. No. 227, Brussels.

Kaiserlian, D., Cerf-Bensussan, N. and Hosmalin, A. 2005. The mucosal immune system: from control of inflammation to protection against infection. Journal of Leukocyte and Biology, 78: 311-318.

Malini, M. and Savitha, J. 2012. Heat stable bacteriocin from Lactobacillus paracasei subsp. tolerans isolated from locally available cheese: An in vitro study. Journal of Biotechnology and Pharmaceutical Research, 3(2): 28-41.

Malini, M. and Savitha, J. 2012. Detection of heat stable bacteriocin from Lactobacillus acidophilus NCIM5426 by liquid chromatography/ mass spectrometry. Indian Journal of Science and Technology, 5(3): 23252332.

Ogunbanwo, S.T., Sanni, A., Onilude, A.A. 2003. Characterization of bacteriocin produced by Lactobacillus plantarum F1 and Lactobacillus brevis OG1. African J. of Biotechnol., 2(8): 219227.

Oh, S., Kim, S.H. and Worobo, RW. 2000. Characterization and purification of a bacteriocin produced by a potential probiotic culture, Lactobacillus acidophilus 30SC. Journal of Dairy Science 83: 2747-2752.

Rajaram, G., Manivasagan, P., Thilagavathi, B., Saravanakumar, A.
2010. Purification and Characterization of a Bacteriocin produced by Lactobacillus lactis isolated from marine environment. Advanced Journal of Food Science and Technology, 2(2): 138-144.

Ray, B., Miller, K. and Jain, M. 2001. Bacteriocins of lactic acid bacteria: current prospective. Indian Journal of Microbiology, 41:1-21.

Simova, E.D., Beshkova, D.B., Dimitorv, Zh.P. 2009. Characterization and antimicrobial spectrum of bacteriocins produced by lactic acid bacteria isolated from traditional Bulgarian dairy products. Journal of Applied Microbiology 106: 692-701.

Tahara, T. and Kanatani, K. 1996. Isolation, partial characterization and mode of action of acidocin J1229, a bacteriocin produced by Lactobacillus acidophilus JCM1229. Journal of Applied Bacteriology 81: 669-667.

Todorov, S. D., Dicks, L. M. T. 2004. Comparison of two methods for purification of plantaricin ST31, a bacteriocin produced by Lactobacillus plantarum ST31. Enzyme and Microbiology Technology, 36: 318326.

Z'Graggen, W.J., Fankhauser, H., Lammer, F., Bregenzer, T. and Conen, D.2005. Pancreatic necrosis infection due to Lactobacillus paracasei in an immunocompetent patient. 